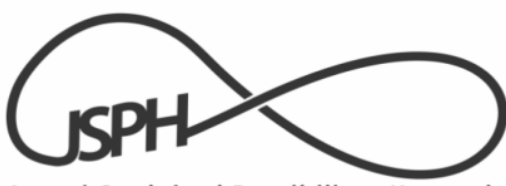

P-ISSN : 2502-7875 E-ISSN : 2527-5879

\title{
DOA SEBAGAI BENTUK PERTUKARAN EKONOMI
}

\section{Rona Bethari Sugianto ${ }^{1}$, Wida Ayu Puspitosari}

Jurusan Sosiologi, Fakultas Ilmu Sosial dan Ilmu Politik, Universitas Brawijaya

${ }^{1}$ Email : ronabethari1096@gmail.com

\begin{abstract}
Abstrak
Penelitian ini membahas praktik pertukaran sosial pada kegiatan doa bersama di Panti Asuhan ' $\mathrm{X}$ ' Kota Sidoarjo. Kegiatan doa bersama di Panti asuhan ' $X$ ' Sidoarjo rutin dilakukan oleh dua donatur utama yang sekaligus menjadi salah satu informan utama penelitian ini. Tujuan penelitian ini yakni mengetahui bagaimana praktik pertukaran sosial dengan menggunakan teori pertukaran sosial milik George C. Homans. Berfokus melihat dan mengalisa bagaimana praktik doa bersama merupakan sebuah sarana pertukaran ekonomi bagi donatur. Metode yang digunakan dalam penelitian ini ialah kualitatif deskriptif dengan subyek penelitian sebanyak tiga orang informan utama yang terdiri dari pemilik panti asuhan dan dua donatur utama panti asuhan. Penelitian ini menggunakan teknik pengumpulan data yakni observasi, wawancara, dan dokumentasi. Hasil dari penelitian ini memperlihatkan Pertukaran sosial yang terjadi antara pengurus panti asuhan dan donatur pada kegiatan doa bersama membungkus pertukaran yang sebenarnya bersifat ekonomi. Dimana, kedua donator melaksanakan doa bersama sebagai wujud pelaksanaan program CSR dan kewajiban membayar zakat. Hal ini kemudian memberikan efek ketenangan hati bagi kedua donator atas gugurnya kewajiban ekonomi dan agama yang melekat pada keduanya.
\end{abstract}

Kata kunci : Doa, Pertukaran Sosial, Pertukaran Ekonomi

\section{PRAYER AS A FORM OF ECONOMIC EXCHANGE}

\begin{abstract}
This study discusses the practice of social exchange at joint prayer activities at the ' $\mathrm{X}$ ' Orphanage in Sidoarjo. The joint prayer activities at the ' $\mathrm{X}$ ' Sidoarjo Orphanage were routinely carried out by two main donors who at the same time became one of the main informants of this study. The purpose of this study is to know how to practice social exchange using the social exchange theory of George C. Homans. There are five propositions presented by Homans in his exchange theory which are the main discussion in this study. The method used in this study is descriptive qualitative with the subject of research as many as three main informants consisting of orphanage owners and two main donors to the orphanage. Data collection techniques are observation, interviews, and documentation. The results of this study show that social exchanges that occur between orphanages and donors in prayer activities together wrap exchanges that are actually economic. Where, both donors carry out joint prayers as a manifestation of the implementation of CSR programs and the obligation to pay zakat. This then has the effect of peace of mind for the two donors over the fall of economic and religious obligations inherent in both.
\end{abstract}

Keywords : prayer, social exchange, economic exchange 


\section{PENDAHULUAN}

Badan Pusat Statistik (BPS) telah memetakan penduduk Indonesia menurut agama yang mereka yakini. Islam sendiri merupakan agama dengan jumlah penganut terbanyak hingga saat ini yakni 207.176.162 jiwa dari total 240 juta jiwa penduduk Indonesia (BPS 2010). Kuantitas ini menunjukkan bahwa Islam dan sekaligus muslim menjadi kelompok mayoritas yang berpengaruh di Indonesia.

Kuantitas penduduk yang menganut agama islam lebih dari $50 \%$ total penduduk Indonesia secara keseluruhan, menjadikannya memiliki peran cukup penting bagi setiap pembentukan dan pelaksanaan kebijakan negara. Hal ini dapat dilihat dari banyaknya lembaga yang berbasis agama, khususnya islam atau yang lazim dijumpai dengan sebutan syariah. Organisasi semacam Majelis Ulama Indonesia (MUI), Pengurus Besar Nahdlatul Ulama (PBNU), dan Muhammadyah, merupakan beberapa contoh organisasi berbasis agama Islam yang ada di Indonesia dan memiliki pengaruh yang cukup penting. Contohnya Majelis Ulama Indonesia (MUI) menjadi lembaga yang berperan sebagai 'titik terang' bagi muslim Indonesia dalam berperilaku yang diwujudkan dalam fatwa-fatwa. Fatwa ini menjadi salah satu sumber penting tentang batasan bagi muslim dalam melaksanakan ataupun mempercayai suatu hal. Dalam hal ini, agama tidak lagi menjadi suatu keyakinan yang bersifat non materil saja namun juga menjelma dalam bentuk material yang diterapkan dan dilaksanakan dalam kehidupan sehari-hari (Moch. Fakhruroji 2012). Konsep agama tidak lagi hanya soal pengetahuan belaka namun ikut menjadi suatu hal yang bersifat kultural. Fenomena ini kemudian mengindikasikan terjadinya privatisasi agama yang tercermin dalam kegiatan sehari-hari, seperti halnya halal dan haram, cara berpakaian, serta ritual keagamaan, seperti doa bersama dan atau kegiatan bersedekah.

Privatisasi tak lepas dari fenomena globalisasi, yang akhirnya ikut serta dalam membentuk masyarakat yang individualis. Sehingga memunculkan konsekuensi ciri masyarakat modern yang mendiferensiasikan fungsi-fungsi yang bersifat dasar. Hal ini menimbulkan terjadinya privatisasi agama yang berkembang saat ini (Moch. Fakhruroji 2012). Privatisasi agama sendiri menurut Luhman dalam (Moch. Fakhruroji 2012) diterjemahkan sebagai sebuah kombinasi pengambilan keputusan yang diprivatisasi khususnya mengenai agama yang dibarengi dengan penolakan pengaruh publik pada masyarakat dalam sistem, profesional, pemerintah atau pemuka agama. Dalam hal ini dijelaskan bahwa ketika terjadi privatisasi agama, maka agama tidak lagi bersifat doktrinal.

Agama kemudian saat ini tidak lagi menjadi sumber nilai dalam pembentukan gaya hidup, namun menjadi salah satu instrumen bagi gaya hidup itu sendiri (Moch. Fakhruroji 2012). Artinya agama yang awalnya bersifat sakral kemudian lambat laun mulai ikut menyentuh segala sesuatu yang bersifat profan. Hal-hal profan yang seringkali bersentuhan dengan agama yakni seperti masalah kemiskinan, kelaparan, politik, ekonomi, dan lainnya. Sehingga ketika ranah profan tersentuh privatisasi agama maka memungkinkan agama menjadi produk yang dapat diperjual belikan ataupun dipertukarkan.

Konsekuensi dari fenomena ini maka timbul adanya standarisasi pada semua aspek termasuk aspek profan. Pada akhirnya tidak sedikit dari masyarakat yang menilai dan mengukur kesalehan dari apa yang dapat dilihat secara indrawi. Lebih lanjut globalisasi menjadikan terjadinya pergeseran agama yakni nilai simbol dari sebuah barang yang mendominasi (Abdullah 2007). Kemudian kesalehan diwujudkan dalam simbol-simbol barang atau sikap dan bukan lagi hanya berkutat pada ranah pengetahuan. Dengan kata lain, hal ini sampai pada pendapat efektivitas agama atau kesalehan sama dengan mengkonsumsi simbol yang berhubungan dengan agama. Proses selanjutnya, beragama ataupun menjalankan ritual keagamaan akan selalu timbul suatu hal yang dapat dipertukarkan.

Kesalehan sendiri diartikan sebagai sebuah perwujudan iman kepada Allah dengan 
mengabdi jiwa, raga, dan harta kepada Allah SWT, serta mengingat (berdzikir) dan memohon ampun kepada Allah, berusaha dengan sungguhsungguh menjalankan perintah Allah dan menjauhi larangan-Nya (ahmad saefudin zuhri, syamsul hidayat 2014; Hasan 2009). Artinya kesalehan merupakan bentuk hubungan manusia dengan Tuhan yang mereka yakini melalui ajaran agama yang sudah terinternalisasi dalam diri seseorang dan tercermin dalam sikap dan perilaku sehari-hari (Mayasari 2014). Sikapsikap yang dilaksanakan kemudian harus mencerminkan perintah agama yang telah diajarkan, artinya secara tidak langsung perlu justifikasi dari orang lain agar apa yang kita lakukan benar-benar telah mencerminkan agama yang kita yakinini khususnya islam.

Fenomena-fenomena yang telah dijelaskan diatas telah peneliti lihat pada kegiatan doa bersama yang dilaksananan di Panti Asuhan ' $X$ ' Sidoarjo. Pertama, peneliti melihat bahwa panti asuhan ' $X$ ' berusaha membingkai keadaan di panti asuhan sebagai sebuah tempat yang wajib diberi bantuan. Hal ini terlihat dari bentuk fisik bangunan, keadaan fisik anak-anak asuh, serta kegiatan sehari-hari yang dilaksanakan. Ditambah beberapa tahun belakangan pemilik panti asuhan terus menerus menambah jumlah anak asuh hingga tak jarang 'berburu' ke daerah-daerah. Kemudian ini menjadikan panti asuhan ' $\mathrm{X}$ ' seringkali diberitakan atas kontradiksi antara jumlah anak dengan fasilitas dan cara merawat anak asuhnya.

Lebih lanjut sedekah atau bantuan yang diberikan donatur seharusnya mencerminkan kesalehan itu sendiri, yakni menjalankan perintahnya dan menjauhi larangannya. Namun ketika bantuan (dalam hal ini merupakan sebuah hal profan) bersentuhan dengan agama yakni bersedekah, peneliti berupaya menarik hal ini dengan apa yang disampaikan George C. Homans sebagi sebuah konsep pertukaran sosial. Bagaimana sebuah ritual agama dapat dipertukarkan dengan sesuatu hal yang menguntungkan kedua belah pihak.

Hal ini terlihat dari banyak donatur yang berasal dari berbagai kalangan yang memberikan bantuan namun meminta hal lain untuk dilakukan oleh para pengurus. Banyak donatur yang datang kemudian meminta para pengurus untuk melakukan doa bersama dengan para anak yatim piatu yang ada di panti asuhan tersebut. Ada donatur yang merupakan pelajar dan akan menghadapi Ujian Nasional, donatur sedang merayakan ulang tahun, ada pula yang sanak saudaranya mengalami sakit, dan beberapa alasan lainnya. Keberagaman latar belakang dan tujuan donatur inilah yang kemudian semakin menunjukkan adanya praktik pertukaran sosial.

Interaksi yang terjadi antara pengurus dan donatur memperlihatkan terdapat sesuatu yang nantinya digunakan sebagai salah satu jalan untuk mencapai tujuan yang ingin dicapai oleh masing-masing pihak. Hal tersebut terbentuk dari sosialiasi antar kedua pihak dengan adanya kegiatan doa bersama ini. Kemudian peneliti melihat terdapat hal-hal yang telah dilakukan oleh pengurus ataupun donatur dalam mempertahankan panti asuhan dan kegiatan doa bersama ini. Setiap harinya pengurus panti asuhan melalui Pemilik panti asuhan akan menghubungi donatur utama untuk memberikan informasi mengenai perkembangan anak-anak panti asuhan.

Semua hal yang telah dijelaskan diatas kemudian bermuara pada sebuah pertanyaaan mendasar, kemudian untuk apa sebenarnya para donatur melakukan doa bersama. Sebuah implementasi kesalehan semata atau ada hal-hal yang memang benar-benar dipertukarkan. Peneliti ingin melihat lebih jauh bagaimana bentuk pertukaran yang terjadi di Panti asuhan ' $X$ ' Kota Sidoarjo, Jawa Timur antara pengurus dan donatur utama. Doa bersama yang dilakukan dirasa tidak murni sebagai kegiatan rutin oleh pengurus dan donatur melainkan terdapat hal-hal dibalik itu yang dapat dipertukarkan oleh kedua belah pihak. Kemudian praktik doa bersama antara pengurus dan donatur ini nantinya dianalisa bagaimana pertukaran sosial milik George C. Homans. 


\section{METODE PENELITIAN}

Jenis penelitian yang digunakan dalam penelitian ini ialah penelitian kualitatif. Yakni bermaksud memahami fenomena tentang apa yang dialami oleh subjek penelitian secara holistik atau keseluruhan. Melalui cara deskripsi dalam bentuk kata-kata dan bahasa, pada suatu konteks khusus yang alamiah dan dengan memanfaatkan berbagai metode ilmiah. (Moelong 2012).

Penelitian kualitatif menekankan pada mencari sebuah makna, konsep, pengertian, simbol, maupun deskripsi tentang suatu fenomena yang mengutamakan data, serta disajikan dalam bentuk narasi (Prof. Dr. Endang Widi Winarni 2018). Karena kualititatif berupaya menemukan penjelasan atas sebuah fenomena secara holistik maka jenis ini dirasa tepat dalam menjelaskan praktik pertukaran sosial yang terjadi di Panti Asuhan ' $\mathrm{X}$ ' Sidoarjo yang menjadi pokok bahasan utama dari peneliti. Selain itu obyek penelitian secara kualitatif dilihat sebagai sesuatu yang dinamis, memiliki pikiran dan perasaan (Moelong 2012), sehingga hal ini mempermudah peneliti dalam memperoleh informasi dan keabsahan data yang diberikan oleh informan.

Teknik penentuan informan merupakan teknik pengambilan sampel guna mempermudah menentukan sampel yang digunakan dalam penelitian. Teknik yang digunakan pada penelitian kali ini adalah Nonprobability Sampling terkhusus purposive sampling. Nonprobability Sampling adalah teknik pengambilan sampel yang tidak memberi peluang atau kesempatan yang sama bagi setiap unsur atau anggota populasi untuk dipilih menjadi sampel (Prof. Dr. Endang Widi Winarni 2018). Sedangkan purposive sampling sendiri merupakan teknik pengambilan sampel dari sumber data melalui pertimbangan tertentu. Informan pada penelitian kali ini sebanyak tiga orang informan kunci, yakni satu orang merupakan pemilik dan pengelola panti asuhan $(\mathrm{G})$ dan dua orang sisanya merupakan donatur utama (Bapak KW dan Ibu P) yang setiap harinya mengirimkan bantuan dan beberapa kali melaksanakan doa bersama.
Alasan peneliti memilih ketiga orang informan tersebut diantaranya, G merupakan pihak yang mengatur segala bentuk keuangan yang berputar di Panti Asuhan. Informan selanjutnya yakni Bapak KW dan Ibu P yang merupakan donatur utama. Donatur KW sendiri merupakan seorang pengusaha yang bergerak di bidang pengiriman dan logistik. Sementara donatur $P$ juga merupakan seorang pengusaha yang bergerak di bidang kuliner.

Selanjutnya terdapat beberapa informan tambahan yang berasal dari panti asuhan yakni tiga pengurus panti asuhan lainnya, satu diantaranya seorang pengasuh dan dua sisanya merupakan pengurus sekretariat. Dari ketiga informan tambahan ini peneliti mendapatkan informasi mengenai bagaimana alur pelaksanaan doa bersama secara teknis maupun substantif. Selain alur pelaksanaan doa bersama, dari ketiga informan ini peneliti mendapatkan informasi terkait sejarah serta gambaran umum panti asuhan. Sehingga kedua informan ini banyak membantu substansi penulisan pada bab empat. Selain informan tambahan dari panti asuhan, peneliti juga memilih informan dari pihak donatur diantaranya $\mathrm{L}$ yang merupakan karyawan dari donatur KW. Melalui informan L, peneliti mendapatkan informasi terkait perusahaan yang dimiliki dan diajalankan $\mathrm{KW}$

\section{HASIL DAN PEMBAHASAN \\ Pertukaran Pengetahuan Agama sebagai Stimulus}

Sebelum memutuskan melakukan sesuatu, individu terlebih dahulu telah mendapatkan stimulus yang mereka dapatk dari dalam ataupun dari luar dirinya. Stimulus ini dapat berupa pengalaman-pengalaman baru maupun yang sudah terjadi yang terwujud melalui pengetahuan dan atau tindakan (Notoatmodjo 2003). Pengetahuan sendiri merupakan mengingat materi yang sebelumnya telah dipelajari dan atau rangsang yang telah diterima (Aminudin 2016). Dalam kegiatan doa bersama, sebelum memutuskan melaksanakan doa bersama di Panti Asuhan ' $X$ ', kedua donatur utama telah mendapatkan stimulus berupa pengetahuan agama khususnya mengenai 
manfaat doa bersama khususnya doa yang dipanjatkan oleh anak yatim.

Pengetahuan agama mengenai doa atau manfaat doa dari anak yatim piatu didapatkan donatur dari beberapa pihak. Namun peneliti melihat bagaimana $G$ (selaku pemilik dan pengembil keputusan di panti asuhan) memiliki andil yang cukup besar dalam pertukaran pengetahuan agama terkait manfaat doa bersama. Pendapat yang diutarakan informan $\mathrm{P}$ :

"Kita sebagai muslim wajib berdoa juga pasti paham lah ya, berdoa itu untuk apa. Kalau untuk saya, doa seperti semacam senjata. Semacam keinginan yang kita panjatkan kepada Allah."

(Wawancara Informan P, 28 Januari 2019, 15.35 WIB)

Lebih lanjut $\mathrm{P}$ menambahkan bahwa pengetahuan mengenai manfaat doa anak yatim sedikit banyak didapatkan dari G, pemilik panti asuhan. Hal ini sebagaimana yang disampaikan oleh P :

"Saya sering sekali sharing karna semakin tua begini apalagi yang dicari. Memang ingin lebih dekat dengan Allah dengan berbagi saja. Hati juga lebih tenang. Daripada belanja yang aneh-aneh, lebih baik diberikan kepada yang kekurangan dan membutuhkan. Lebih bermanfaat, pahalanya dapat, manfaatnya dapat." (Wawancara Informan P, 28 Januari 2019, 15.35 WIB)

P juga menambahkan :

"Sharingnya macam-macam, Karena saya ibaratnya pemula. Jadi sering sekali bertanya sama G. Kalau diberi waktunya banyak ya gimana kita bisa jadi orang yang agamanya bagus dan kuat. Terus apa yang bisa dilakukan supaya hidup tu lebih bermanfaat. Kalau soal anak yatim, ya jelas bagaimana $\mathrm{G}$ mengelola panti asuhannya. Terus bisa ikhlas mengasuh. Kan ya tidak gampang, sama luar biasanya doa anak yatim untuk kita semua. Khususnya muslim ya"

(Wawancara Informan P, 28 Januari 2019, 15.35 WIB)

Hasil wawancara ini menunjukkan bagaimana $G$ selaku pemilik panti asuhan menjadi salah satu pihak yang ikut serta dalam mempertukarkan pengetahuan kepada $\mathrm{P}$ terkait keutamaan doa anak yatim. Pertukaran sosial yang terjadi antara pengurus panti asuhan dengan donatur terkait pengetahuan mengenai doa bersama dapat dikatakan baik pada tahap ini. Dimana donatur $\mathrm{P}$ dengan sukarela menerima pengetahuan itu dan didukung atas pengetahuan yang didapat tidak hanya di panti. $\mathrm{P}$ lebih cenderung mendapatkan pengetahuan mengenai keutamaan doa melalui hal-hal yang dibagikan $G$ kepada $P$ dalam beberapa kesempatan. Pendapat yang sama diutarakan oleh KW, donatur utama lainnya yang mengatakan :

"Setau saya doa anak yatim itu mustajab, akan dikabulkan lebih udah oleh Allah. dan saya memang meyakini itu dan bantuan Allah memang nyata. saya tidak minta, sudah dikasih lebih."

(Wawancara Informan KW, 28 Januari 2019, 10.00 WIB)

Donatur KW memiliki pengetahuan yang sedikit berbeda mengenai keutamaan doa anak yatim jika dibandingkan dengan yang dimiliki $P$. KW mengatakan bahwa pengetahuan mengenai doa anak yatim ia dapatkan atas dasar pengalaman yang ia dapatkan langsung. KW berpendapat bahwa sejak ia duduk di bangku Sekolah Menengah Pertama ia telah menjadi anak yatim. Hal ini menurut dia menjadi salah satu dasar bahwa anak yatim piatu merupakan salah satu pihak yang wajib ia bantu ketika ia sudah memiliki banyak uang. Pendapat KW mengenai hal ini disampaikan melalui wawancara :

"saya ngrasa yang saya punya itu untuk apa. anak-anak saya insyaAllah juga sudah terpenuhi. saya belajar untuk cukup, sekarang sudah waktunya untuk mendekatkan diri sama Allah. Dan yang membutuhkan bantuan kan ya pasti mereka yang apa ya memang butuh bantuan toh. Dan menurutku anak-anak khususnya yatim piatu itu butuh sekali dan ingat saya juga dulu sejak smp sudah tidak punya ibu. Yaitu saya ngrasa, anak yatim yang memang lebih butuh daripada saya begitu"

(Wawancara Informan KW, 28 Januari 2019, 10.00 WIB) 
Pendapat ini mendapat justifikasi dari $\mathrm{G}$ selaku pemilik panti asuhan yang ketika $\mathrm{P}$ maupun KW bertemu dengan $G$ saat doa bersama maupun diluar doa bersama seringkali $\mathrm{G}$ memberikan pengetahuan agama mengenai pengalamannya dalam mengurus panti asuhan dan manfaat yang didapat dari mengurus anak yatim. Dari pendapat KW dan P diatas, dapat ditarik sebuah pembahasan bahwa pihak pengurus panti asuhan khususnya $G$ berperan aktif dalam menambah pengetahuan agama terkait manfaat doa dari anak yatim. Hal ini peneliti alami ketika berada di lapang dan melakukan wawancara tidak terstruktur dengan G yang menyatakan :

"ya begitu memang mbak, saya kadangkadang juga ndak ngira gitu bisa ngasuh anak 200, Alhamdulillah sehari saja tidak pernah kekurangan. Pasti ada saja yang bantu, memang Allah sudah menjanjikan kepada umatnya, yang membantu mereka yang membutuhkan maka akan kupermudah segala urusannya. Kan begitu. memang jangan lah kau menghardik anak yatim. Kan begitu larangannya"

(Wawancara Informan G, 10 November 2018, 16.18 WIB)

G juga menambahkan :

"nah iya bisa, nanti doa bareng-bareng sama anak-anak disini. Kita kumpulkan semua terus doa. InsyaAllah nanti pasti Allah kabulkan. Anak-anak disini kan kasihan mbak. Masih kecil sudah tidak punya bapak tidak punya ibu. Allah pasti kan seneng dengan hambanya yang membantu sesama. Ibarat kendaraan ya mbak, apa yang diberikan itu ibarat kendaraan. Pasti membantu kita untuk mendapat hal-hal baik, insyaAllah surga balasannya. Makin tabungan amal baiknya kita banyak, makin kendaraannya itu bagus."

(Wawancara Informan G, 10 November 2018, 16.18 WIB)

Pertukaran sosial antara donatur utama dengan pengurus panti asuhan terkait pengetahuan agama mengenai manfaat doa bersama khususnya dari anak yatim piatu menunjukkan hubungan sosial yang baik. Dimana $G$ ikut membangun kesadaran para donatur akan pentingnya membantu sesama khususnya anak yatim serta bagaimana manfaat yang akan diperoleh jika mendapatkan doa dari anak yatim piatu. Pengetahuan yang didapatkan oleh kedua donatur tidak serta merta dibentuk dalam waktu yang singkat. Stimulus pengetahuan ini didapatkan dengan terus menerus yang kemudian menimbulkan kesadaran baru bagi para kedua donatur.

Sebagaimana KW dan P katakan, bahwa KW telah memiliki pengalaman akan menjadi anak yatim dan pengetahuan yang dibagikan oleh $G$ mengenai manfaat anak yatim serta bagaimana mereka membutuhkan bantuan. Begitu pula yang disampaikan oleh $\mathrm{P}$, dimana pengetahuan mengenai manfaat doa anak yatim telah $\mathrm{G}$ bagikan sejak awal pertemuan mereka. Pengetahuan-pengetahuan yang ditransfer oleh G mengenai manfaat doa yang dipanjatkan anak yatim menjadi sebuah stimulus yang kemudian mengalami terus menerus disepakati dan dijalankan oleh para donatur. Sehingga, stimulus berupa pengetahuan ini kemudian oleh para donatur ditransformasikan menjadi sebuah nilai dan atau kesadaran baru yang penting dan ikut melanggengkan kegiatan doa bersama.

Pengetahuan mengenai manfaat doa dari anak yatim ini kemudian peneliti lihat tidak hanya menjadi sebuah interaksi dan tukar informasi antara donatur dan penilik panti asuhan. Lebih dari itu, G mencoba untuk mempertukarkan hal yang bersifat non materi yang ia miliki yakni pengetahuan itu sendiri dengan sebuah peluang yang nantinya dapat berwujud hal yang bersifat materi. Temuan ini didasarkan atas segala pengetahuan yang coba diberikan oleh $\mathrm{G}$ kepada kedua donatur ataupun kepada pengunjung lainnya yang bermuara kepada saran untuk melakukan doa bersama di panti asuhan.

Pengetahuan disini peneliti lihat sebagai salah satu hal dasar yang dipertukarkan oleh $G$ kepada KW dan P. Namun peneliti juga melihat bahwa terdapat hal yang bersifat sangat ekonomis yang KW dan P tukarkan kepada G dalam kegiatan doa bersama ini. Sehingga terdapat perbedaan ketika kedua pihak mencoba membangun keinginan untuk melaksanakan doa bersama. Jika $G$ selaku pemilik panti asuhan 
mencoba menukarkan pengetahuan yang ia miliki agar donatur melaksanakan doa bersama di panti asuhan, KW dan $\mathrm{P}$ memiliki hal yang sangat ekonomis hingga akhirnya mau melaksanakan doa bersama. Hal ini akan dijelaskan di sub bab selanjutnya.

\section{Doa bagi Donatur P: Mengurangi Beban, Menghindari ketidaksukaan}

Jika pada sub bab sebelumnya peneliti menyatakan bahwa terdapat pertukaran yang bersifat non materi, dalam hal ini adalah pengetahuan yang dipertukarkan oleh pengurus panti asuhan kepada kedua donatur. Kemudian pada sub bab ini, peneliti melihat sebuah pertukaran yang bersifat ekonomis yang mendasari para donatur untuk melakukan doa bersama. Nyatanya pengetahuan terkait agama tidak menjadi satu-satunya alasan para donatur melakukan doa bersama.

Saat doa bersama berlangsung, pengurus panti asuhan akan menanyakan keperluan memberikan bantuan. Apakah hanya ingin memberi bantuan atau ada hajat yang ingin dilakukan dan dipenuhi. Hajat disini sama dengan keinginan-keinginan yang ingin dicapai. Melalui wawanncara yang dilakukan dengan kedua informan utama, dijelaskan bahwa alasan pertama kali mereka melakukan doa bersama yakni memiliki acara diantaranya syukuran dan ulang tahun salah seorang anak dari salah satu donatur. Alasan-alasan selanjutnya para donatur melakukan doa bersama yakni sebagai wujud syukur kepada Allah. Kedua donatur sepakat bahwa doa dari anak yatim merupakan doa yang didengar oleh Allah, dan karena melaksanakan doa bersama mereka merasa mendapatkan manfaat yang luar biasa.

Kemudian, menurut Homans mengenai teori pertukaran yang ia buat bahwa dalam proses pertukaran manusia atau individu tidak hanya mempertukarkan hal yang bersifat materi saja namun mungkin untuk bertukar hal yang bersifat non materi sangat memungkinkan untuk terjadi (Poloma 2004). Hal non materi dijelaskan Homans sebagai sesuatu yang didasarkan atas emosi. Namun terlepas dari itu, Homans melihat bahwa pertukaran yang terjadi tidak keluar dari prinsip dasar ekonomi, dimana perkembangan stimulus-respon dan atau reward-punishment menjadi dasar untuk bertukar.

Dalam hal ini, doa bersama yang dilakukan para donatur dapat dikatakan merupakan upaya mengurangi mengurangi beban dan menghindari ketidaksukaan yang jika ditarik menjadi sesuatu yang lebih singkat bersifat ekonomis. Pertimbangan stimulus dan reward-punishment menjadi pijakan awal dari pelaksaan doa bersama yang diadakan di panti asuhan X. Hal ini sebagaimana yang dikatakan informan P:

"saya nyaman saja ketika bertemu dengan anak-anak. Senang bisa berbagi kepada orang lain. Apalagi anak-anak yang membutuhkan. Karena bapak saya sudah tidak ada pas saya kecil, jadi ya kasian gitu. Seneng lah bisa bantu orang lain yang bener-bener membutuhkan" (Wawancara Informan P, 28 Januari 2019, 15.35 WIB)

$\mathrm{P}$ menambahkan :

"kita sebagai manusia harus saling membantu. Apalagi kan 2,5\% dari apa yang kita miliki itu bukan punya kita. Jadi memang harus dibagikan kepada orang lain. Selama masih ada umur dan rezeki ya jalan terus. Buat apa hidup ini kalau tidak bermanfaat untuk orang lain. InsyaAllah dapat ganjarannya surga. Menyantuni anak yatim nanti katanya kan ganjarannya surga. Kalau sudah tua gini apalagi yang dicari kalau ngga dekat sama yang kuasa. Nabung Amal"

(Wawancara Informan P, 28 Januari 2019, $15.35 \mathrm{WIB})$

Ada dua hal utama yang dapat dilihat dari pernyataan informan $\mathrm{P}$, pertama adalah dimana stimulus dimasa lalu yakni perasaan sama ketika kehilangan orang tua dapat menjadikannya untuk memperlakukan dan memberikan bantuan kepada anak-anak yatim sebagai respon atas stimulus dimasa lalu. Kemudian yang kedua yakni, setelah mendapat dan memiliki stimulus baik pengalaman dimasa lalu dan atau pengetahuan mengenai manfaat doa dari anak yatim, P kemudian percaya bahwa nantinya bantuan yang diberikan akan mendapatkan 
reward berupa surga. Serta pahala yang disebutnya sebagai tabungan. Pahala menjadi sesuatu yang dicari walaupun harus memberikan sebagian dari apa yang ia miliki. Apa yang diberikan kemudian donatur $\mathrm{P}$ sebut dengan 2,5\% miliknya bukanlah hak yang harusnya ia dapatkan melainkan harus diberikan kepada orang lain.

Panti asuhan dalam penelitian ini menyediakan suatu kebutuhan bagi kedua donatur utama yakni apa yang mereka sebut sebagai ketenangan hati, kesenangan akan membantu yang menurut mereka membutuhkan. Hal ini serupa dengan yang dikatakan Homans (Poloma 2004) : "Seseorang yang berstatus lebih tinggi akan lebih banyak menyediakan barangbarang yang langka dalam hubungannya dengan permintaan, tetapi dia juga akan menerima lebih banyak barang yang tersedia (Homans 1974:195 dan seterusnya)"

Selaras dengan apa yang terjadi di Panti Asuhan X, yakni para donatur memberikan dan menyediakan barang-barang yang dibutuhkan oleh para pengurus atau oleh anak-anak asuh. Kebutuhan berupa makanan, pakaian, kendaraan, dan atau uang yang barang-barang tersebut merupakan barang yang dibutuhkan oleh panti asuhan agar kehidupan didalamnya tetap berjalan. Dari apa yang diberikan oleh para donatur nantinya mereka akan menerima lebih banyak barang yang tersedia disana.

Hal yang donatur bisa dapatkan yakni mengurangi beban bertambahnya usia, merasa tidak melakukan apa-apa, kurangnya pahala, kemungkinan mendapatkan surga, serta mengurangi beban dalam kewajiban melakukan kewajiban muslim berzakat. Maka melakukan doa bersama memberikan sebuah manfaat yang dirasa berlipat-lipat. Dengan pengetahuan akan doa anak yatim menjadikan para donatur sepakat bahwa doa bersama yang mereka lakukan merupakan ladang pahala serta mendapatkan ganjaran yang berlipat-lipat dengan tujuan akhir mendapatkan ganjaran terbesar yakni surga.

Dari sini terlihat bagaimana melalui doa bersama, hal-hal yang ditukarkan oleh kedua donatur dan panti asuhan bersifat sangat ekonomis. Pada kenyataannya, donatur $\mathrm{P}$ mengatakan bahwa setelah melaksanakan doa bersama dengan anak yatim ia merasa mendapatkan rezeki yang walaupun tidak signifikan namun cukup stabil.. Hal ini ia katakan dengan pendapatan rumah makan yang ia miliki cukup stabil beberapa tahun terakhir, dan dapat menambah jumlah karyawan. Hal ini sebagaimana yang disampaikan $P$ :

"kalau signifikan memang ngga sih, karena memang kan kita gaboleh ya berharap seperti itu. Tapi memang gimana ya, saya ya bingung, Maksudnya kan lokasi rumah saya ini sepi, dalem perumahan, terus kecil juga rumah makannya. Tapi ya alhamdulillah stabil lah kalau dikatakan itu. Dari awal buka sampai sekarang juga pegawai tetep, nambah satu malah. Jadi 5 sekarang. Terus buktinya semakin saya sering berdoa rejeki juga ada buat saya kasih lagi ke mereka. Kan ya itu diluar nalar sih

(Wawancara Informan P, 27 April 2019, 10.47 WIB)

Hal ini memberi sebuah penjelasan bahwa $P$ melaksanakan doa bersama tidak hanya sebagai memberi bantuan kepada anak yatim piatu, perwujudan kesalehan, ataupun salah satu ritual kewajiban agama. Namun bersifat ekonomis dan segala sesuatu yang dikeluarkan tidaklah murni tanpa mengharap ganjaran yang setara atau lebih.

\section{Donatur KW : Doa Bersama, Satu Kegiatan untuk Dua Kewajiban}

Sub bab ini membahas mengenai bagaimana doa bersama bagi donatur KW bersifat sangat ekonomis pada awal pelaksanaannya. Lagi-lagi panti asuhan dalam penelitian ini menyediakan suatu kebutuhan bagi kedua donatur utama yakni apa yang mereka sebut sebagai ketenangan hati, kesenangan akan membantu yang menurut mereka membutuhkan. Sebagaimana yang dikatakan Homans (Poloma 2004) : "Seseorang yang berstatus lebih tinggi akan lebih banyak menyediakan barang-barang yang langka dalam hubungannya dengan permintaan, tetapi dia juga akan menerima lebih banyak barang yang tersedia (Homans 1974:195 dan seterusnya)" 
Pernyataan Homans ini kemudian coba peneliti tarik kedalam kegiatan doa bersama menurut donatur KW. Donatur KW, jika dibandingkan dengan donatur $\mathrm{P}$ memiliki latar belakang usaha yang berbeda. Keduanya merupakan pengusaha namun dengan bentuk usaha yang berbeda. Hal ini yang kemudian menjadikan pertukaran yang terjadi pada kegiatan doa bersama berbeda satu sama lainnya.

Seseorang yang berstatus lebih tinggi dalam hal ini adalah KW- atau dapat peneliti sebut sebagai seorang yang status ekonomi yang dimiliki merupakan tertinggi diantara $\mathrm{G}$ ataupun P. Akan lebih menyediakan barang yang langka dalam hubungannya dengan permintaan. Hal ini peneliti lihat dimana ketika pelaksanaan doa bersama, KW menjadi pihak yang menyediakan atau memberi lebih banyak dibanding ketika $\mathrm{P}$ melakukan doa bersama. Selain pengeluaran berupa nasi kotak, ataupun uang, saat pelaksanaan doa bersama KW seringkali menyelipkan kegiatan lainnya seperti pengobatan gratis, pemberian kendaraan, ataupun merenovasi beberapa titik di panti asuhan. Hal ini sebagaimana disampaikan L, salah satu karyawan KW :

“ya bareng, karna sekalian. Soalnya kan bapak kadang-kadang repot, jadi ya kalau pengobatan waktu itu sekalian sama doa sama pas dokter kris bisa. Kalau renov itu aku lupa kapan, bareng atau ngga sama doa. Tapi seinget saya sih selalu bareng. Pokoknya kalau bapak kesana, itu doa. Tapi kalau bapak gak kesana, yasudah kayak kita biasa. Bagi bubur saja." (Wawancara Informan L, 27 April 2019, 14.00 WIB)

Materi baik berupa uang ataupun barang yang telah KW keluarkan, peneliti menemukan sebuah fakta yang kemudian dapat dikatakan sebagai sebuah pertukaran yang bersifat ekonomis melalui wawancara yang telah dilakukan. Peneliti mencoba menghubungkan latar belakang pekerjaan dan usaha yang dimiliki oleh KW dengan alasan yang disampaikan $\mathrm{KW}$ dan $\mathrm{L}$ terkait doa bersama yang dilakukan.
Jika menurut $\mathrm{KW}$, doa bersama dilakukan atas keinginannya mencari sesuatu yang lain yang belum pernah ia dapatkan. Pernyataan berbeda justru disampaikan L, yang merupakan kepala CSR di perusahaan yang dimiliki KW. L menyampaikan bahwa perusahaan yang $\mathrm{KW}$ jalankan selama ini telah memiliki kewajiban sosial dengan adanya CSR. Lebih lanjut L menyatakan bahwa kawasan yang menjadi kewajiban CSR bagi perusahaan yang KW miliki diantaranya disekitar Sidoarjo, Pasuruan, Surabaya dan Malang. Hal ini yang menjadikan seringkali kegiatan sosial yang dilaksanakan berlokasi di wilayah tersebut.

Terkait doa bersama, L menambahkan bahwa :

"iya itu masuk. Tapi doa gimana ya, itu kan sepaket sama kalau kita ngasih bantuan. Jadi bantuannya yang masuk SPJ. tapi pusatnya sini sih. Makanya kegiatannya kan sering disini. Sidoarjo, Gresik, Malang, Tretes."

(Wawancara Informan L, 27 April 2019, $14.00 \mathrm{WIB}$ )

Dari pernyataan L ini terlihat bagaimana ketika pelaksanaan doa bersama, KW melakukan hal tersebut didasarkan atas sebuah hal yang menurutnya bersifat ekonomis. KW mempertukarkan apa yang memang seharusnya ia keluarkan sebagai sebuah kewajiban atas usaha yang ia miliki dengan ganjaran yang bersifat non materi dan materi itu sendiri. L mengatakan bahwa pada awal pelaksaan doa bersama, beberapa kali kegiatan tersebut dibarengi dengan melakukan atau memberikan bantuan berupa renovasi dibeberapa titik di panti asuhan. Renovasi yang pernah dilakukan yakni diantaranya pada kamar mandi, dan panggung panti asuhan. Selain renovasi, donatur KW juga pernah melaksanakan doa bersama dan dibarengi dengan kegiatan pengobatan gratis.

Doa bersama, menjadi sarana bagi KW untuk menggugurkan dua kewajiban sekaligus yang memang harus dijalankan. Kewajiban pertama sebagai umat beragama Islam yakni membantu mereka yang membutuhkan khususnya anak yatim. Dan kewajiban kedua yang menjadi inti pertukaran pada donatur KW yakni menggugurkan kewajiban sosial yang 
memang wajib dipenuhi oleh usaha yang dimiliki KW. Sehingga pada akhirnya, KW sebagai pihak yang memiliki status paling tinggi, dia juga menjadi pihak yang menerima lebih banyak barang yang tersedia.

\section{Efek Pertukaran Sosial Sebagai Kamuflase Pertukaran Ekonomi}

Setelah peneliti menguraikan alasan para donatur dalam melaksanakan doa bersama, yang ternyata tidak hanya didasarkan atas pengetahuan yang dipertukarkan antara pemilik dan panti asuhan. Peneliti kemudian menemukan hal yang dirasakan oleh para donatur pada saat dan setelah doa bersama dilakukan. Hal ini peneliti lihat dari efek pertukaran yang bersifat ekonomis yang kemudian memberikan efek non materi yang juga memberikan ganjaran tersendiri bagi kedua donatur. Efek pertukaran sosial yang dialami oleh kedua donatur yakni kejenuhan dan gugurnya kewajiban ekonomi dan agama. Hal ini selengkapnya akan dijelaskan pada sub bab di bawan ini :

\section{- Kejenuhan Sebagai Efek dari Doa}

\section{Bersama}

Bernilainya doa dari anak yatim selain berasal dari stimulus yang ditransfer oleh $\mathrm{G}$, tak lepas dari beberapa hal yang telah dialami oleh kedua donatur. Sebelum memutuskan untuk mengadakan doa bersama, kedua donatur telah mengalami hal-hal yang menurut pengakuannya bersifat menjemukan. Keduanya memiliki pola jawaban yang sama terkait kejenuhan yang diamali. Dimana, dalam perjalanannya donatur merasa telah memiliki segala sesuatu yang selama ini telah mereka cari. Hal ini sesuai dengan hasil wawancara yang disampaikan donatur KW sebagai berikut :

"sudah tua, sudah merasa cukup lah, sama apa yang didapat. Kan capek ya sudah tua, terus ya ini saatnya menikmati. Nikmatinnya ya kalo dulu buat beli-beli sekarang cari yang lain ya, yang lebih bermanfaat lah". (Wawancara Informan P, 28 Januari 2019, $10.00 \mathrm{WIB}$ )
Pendapat yang sama juga disampaikan oleh donatur P :

"iya, saya sering sekali sharing karna semakin tua begini apasih yang dicari. Memang ingin lebih dekat dengan Allah. Pengen sudah berbagi saja. Kan hati juga tenang. Daripada belanja yang aneh-aneh, mending uangnya dikasih ke yang lebih membutuhkan. Lebih bermanfaat, pahalanya dapet, manfaatnya dapet".

(Wawancara Informan P, 28 Januari 2019, $10.00 \mathrm{WIB}$ )

Perasaan akan "cukup" yang dimiliki oleh kedua donatur menjadikannya mencari sesuatu yang lain agar mendapat ganjaran yang menurut mereka belum didapatkan. Sehingga stimulus tentang pengetahuan mengenai anak yatim dan perasaan kejenuhan ini yang kemudian bermuara pada terlaksananya doa bersama dengan anak yatim yang telah dilakukan. Kedua donatur telah merasa cukup dengan setiap ganjaran -yang selanjutnya mereka rasakan dengan kemampuan membeli dan mendapatkan yang mereka inginkan berupa materi- membuat mereka menginginkan ganjaran yang lain. Hingga kemudian stimulus akan pengetahuan agama terkait manfaat doa anak yatim mereka dapatkan dan menjadi sebuah hal yang bernilai besar.

Pada akhirnya jika dikaitkan dengan apa yang telah terjadi dan dijelaskan pada sub bab sebelumnya, kejenuhan ini dilihat peneliti tidak hanya serta-merta sebuah kejenuhan akan kecukupan yang dimiliki donatur. Kejenuhan ini juga peneliti lihat atas apa yang telah mereka lakukan. Kedua donatur telah melaksanakan kewajiban 'dunia' yakni kewajiban melakukan CSR serta membayar zakat yang terwujud dalam doa bersama. Setelah kewajiban ini terpenuhi, kedua donatur mencoba mencari hal lain yang bisa mereka dapatkan untuk terus melakukan doa bersama. Sehingga kejenuhan yang terjadi tidak hanya terjadi sebelum para donator memutuskan 
melakukan doa bersama, namun terjadi juga setelah mereka melaksanakan doa dan kewajiban CSR dan Zakat.

\section{- Menggugurkan Kewajiban Ekonomi dan Agama}

Ketika pelaksanaan doa bersama berlangsung, sebagaimana yang telah dijelaskan bahwa terdapat dua kewajiban yang telah digugurkan dan ganjaran yang didapatkan oleh kedua donator. Dimana, kewajiban ekonomi telah dilaksanakan oleh kedua donator dalam bentuk doa bersama. Bagi $\mathrm{KW}$, doa bersama telah menggugurkan kewajiban melakukan CSR. Sementara bagi P, ia telah menunaikan kewajibannya membayar zakat. Setelah kewajiban ini gugur, hal lain yang ikut serta gugur adalah kewajiban membantu orang lain. Dalam hal ini, adalah kewajiban beragama khususnya bagi umat Islam. Inilah yang memberikan ketenangan hati bagi keduanya.

Ketenangan hati menurut para donatur dan pengurus kemudian merupakan hal tertinggi yang mereka dapatkan. Hal ini terkait dengan bagaimana para donatur merespon kegiatan yang telah mereka laksanakan dan apa yang mereka rasakan setelah pelaksanaan doa bersama. Salah satu donatur mengatakan perasaan yang diamalami donatur pasca pelaksanaan doa bersama yakni perasaan senang dan perasaan sebagaimana yang tersampaikan dalam pendapat $\mathrm{P}$ berikut:

"iya, saya sering sekali sharing karna semakin tua begini apasih, yang dicari. Memang pengen lebih dekat dengan Allah. Pengen sudah berbagi saja. Kan hati juga tenang. Daripada belanja yang neko-neko, mending uangnya dikasih ke yang membutuhkan. Lebih bermanfaat, pahalanya dapet, manfaatnya dapet." (Wawancara Informan P, 28 Januari 2019, 15.35 WIB)

Pendapat $\mathrm{P}$ yang lain yakni :

"apa ya, yang jelas hati jadi lebih tenang sih. Karna saya tahu secara jelas uang yang saya keluarkan itu kemana perginya. Dan katanya juga kan semakin kita memberi semakin kita akan menerima. Allah kan begitu , katanya. Tapi memang bukan katanya sih "saya merasakan sendiri. Setiap setelah saya melakukan doa bersama, ada saja pasti rezeki datang ke saya itu. Tapi bagi saya rezeki itu nggak selalu berbentuk uang, kayak dulu saya pernah doa bersama menjelang kevin ujian. Alhamdulillah keterima di ITS. Atau apa gitu, selalu ada bantuan yang tiba-tiba. Jadi memang saya semakin percaya bahwa doa yang diberikan orang lain ke kita apalagi doa anak yatim itu sangat sangat bermanfaat bagi kita."

(Wawancara Informan P, 28 Januari 2019, 15.35 WIB)

Perasaan tenang dan senang yang dirasakan donatur tidak terlepas dari apa yang sudah menjadi pengetahuan agama diawal mengenai manfaat doa yang dipanjatkan anak yatim piatu. Pengetahuan agama yang didapatkan dari berbagai sumber menjadikan para donatur terstimulus untuk terus meyakini bahwa apa yang mereka dapatkan baik harta, kebahagiaan, ketenangan merupakan hasil dari doa anak yatim yang telah mereka santuni. $\mathrm{P}$ berpendapat sebagai berikut :

"iya sangat merasakan. Saya merasakan memang doa anak-anak yatim didengar oleh Allah. Dan asalkan kita ikhlas ya insyaAllah pasti allah memberikan yang jauh lebih berlimpah, selama masih ada umur masih ada rezeki ya jalan terus. Buat apa, hidup ini kalau ngga dibuat bermanfaat untuk orang lain. InsyaAllah ganjarannya surga. Menyantuni anak yatim nanti katanya kan ganjarannya surga. Kalau sudah tua gini apa, yang dicari kalau ngga dekat sama yang kuasa. Nabung Amal,"

(Wawancara Informan P, 28 Januari 2019, 15.35 WIB)

Selain itu, kedua donatur sepakat bahwa semakin mereka bertambah usia maka, ketenangan jiwa merupakan kesuksesan tertinggi bagi mereka. Membantu orang-orang yang menurut 
mereka membutuhkan dapat menjadi sarana bagi mereka mendapatkan ketenangan jiwa tersebut, walaupun mereka harus mengeluarkan materi yang mereka miliki. Dengan membantu orang lain yang dirasa membutuhkan bantuan mereka, mereka sepakat bahwa Tuhan akan memberikan hal yang lebih besar dari apa yang telah mereka keluarkan. Semakin banyak jumlah yang dikeluarkan untuk membantu orang yang dianggap membutuhkan -dalam hal ini adalah anak yatim-, maka semakin besar pula Tuhan akan memberikan rezeki.

Kedua donatur menjelaskan bahwa rezeki yang mereka maksud tak hanya berupa uang, namun juga bantuan berupa kelancaran ketika memiliki urusan, serta ketenangan jiwa itu sendiri. Namun pada akhirnya tidak dipungkiri bahwa mereka merasa mendapat materi berupa uang yang jauh lebih banyak ketika mereka melaksakanan doa bersama dengan anak yatim. Hal ini disampaikan oleh donatur KW :

"makanya kan sekarang setiap kegiatan selalu tak selipkan acara sosialnya, acara amalnya. Biar berkah, biar Allah ga pelit ngasih kita. Soalnya kita gak pelit ngasih ke sesama. Begitu aja prinsip hidup saya sekarang" (Wawancara Informan KW, 28 Januari 2019, 10.00 WIB)

Donatur KW menambahkan bahwa dengan adanya doa dari anak yatim dan bantuan yang ia berikan, maka pahala yang didapat akan berlipat ganda. Hal ini sebagaimana disampaikan $\mathrm{KW}$ :

"saya ngrasa ini yang saya punya itu buat apa. anak-anak insyaAllah sudah lah terpenuhi. Apalagi gitu, ya akhirnya aku belajar aku mulai lah kayaknya cukup sekarang wes waktunya mendekatkan diri sama Allah. Dan ya itu, yang membutuhkan bantuan kan ya pasti mereka yang memang butuh bantuan dan menurutku anak-anak khususnya yatim piatu itu butuh banget dan lagi memang saya juga dulu sejak smp gapunya ibu. Ya itu saya ngrasa, anak yatim yang memang butuh dan pahalanya buat kita luar biasa kan."

(Wawancara Informan KW, 28 Januari 2019, $10.00 \mathrm{WIB}$ )

Sampai disini, peneliti kemudian melihat bahwa ketenangan hati tidaklah didapat oleh kedua donatur murni dari sedikit 'jaminan' mendapatkan surga atas doa yang mereka dapatkan dari anak yatim. Namun, ketenangan hati ini lebih didapatkan atas kewajiban ekonomi yang telah mereka selesaikan. Seperti yang selalu peneliti tekankan pada setiap pembahasan, yakni terkait kewajiban melakukan CSR dan Zakat. Sehingga ketenangan yang didapatkan para donator dapat dikatakan berawal dari terselesaikannya kewajiban secara birokratis yani CSR dan zakat itu sendiri. Baru setelah ketenangan dari hal ekonomis tersebut kedua donator mendapat ketenangan hati yang lain yang bersifat religius. Yang kemudian, berawal dari hal inilah doa bersama dapat menimbulkan efek ketenangan hati bagi kedua donatur.

\section{PENUTUP}

Pertukaran sosial pada proses doa bersama dengan anak yatim terjadi bahkan sebelum doa bersama dilakukan. Yakni melalui transfer pengetahuan agama mengenai manfaat doa anak yatim. Pengetahuan yang ditransfer oleh $G$ selaku pemilik panti asuhan berupa pengetahuan agama tentang manfaat doa yang dipanjatkan oleh anak yatim. Para donatur mengatakan bahwa $G$ beberapa kali ketika bertemu menyampaika pentingnya membantu sesama manusia khususnya anak yatim. G melalui pernyataan informan $\mathrm{KW}$ dan $\mathrm{P}$ berkata bahwa doa anak yatim akan menembus langit ke tujuh dan ini berarti harapan-harapan atau keinginan akan lebih cepat dikabulkan.

Selain terkait pengetahuan agama, pertukaran sosial pada kegiatan doa bersama ini peneliti lihat sebagai sebuah hal diawali dari kegiatan ekonomi bagi kedua donatur. Donatur 
KW melakukan doa bersama dibarengi dengan kegiatan bakti sosial yang biasa dilakukan oleh perusahaan yang ia miliki. Sehingga doa bersama ini merupakan salah satu kegiatan CSR bagi perusahannya. Kemudian bagi donatur $\mathrm{P}$, kegiatan doa bersama ini selain kegiatan membantu anak yatim piatu yang ada disana juga sebagai sarana melakukan kewajiban membayar zakat. Donatur $\mathrm{P}$ menyebut dari seluruh apa yang ia miliki, 2,5\% nya bukanlah milik dia dan wajib untuk dibayarkan atau diberikan kepada mereka yang membutuhkan.

Setelah hal yang bersifat ekonomis, pelaksanaan doa bersama kemudian memberikan efek bagi kedua donatur yakni mendatangkan kepuasan hati.. Kepuasan serta ketenangan hati, menjadi hal yang didapatkan oleh KW dan $P$ begitu pula $G$ setelah menggugurkan kewajiban ekonomi maupun agama lewat doa yang telah mereka lakukan. Para donatur dengan panti asuhan menukarkan sesuatu yang bersifat materi dalam hal ini berupa bantuan, uang, dan atau barang-barang.

\section{DAFTAR RUJUKAN}

Abdullah, Irwan. (2007). Konstruksi dan Reproduksi Kebudayaan. Yogyakarta: Pustaka Pelajar.

Ahmad Saefudin Zuhri, syamsul hidayat, abdul khaliq hasan. (2014). "Individu Menuju Kesalehan Sosial Di Era-Globalisasi." Universitas Muhammadiyah Surakarta 2-9.

Aminudin, Mukhamamad. (2016). "Hubungan Antara Pengetahuan dan Sikap Dengan Perilaku Konsumsi Jajanan Sehat di MI SULAIMANIYAH Mojoagung Jombang." Universitas Airlangga 26.

Beny. (2014). "Sedekah dalam perspektif hadis." Universitas Islam Negeri Syarif Hidayatullah Jakarta 14-15.

BPS. (2010). "Sensus Penduduk 2010 Penduduk Menurut Wilayah dan Agama yang Dianut Indonesia." www.bps.go.id 1. Diambil 23 April 2018 (https://sp2010.bps.go.id/index.php/site/ tabel?tid=321).
Burhan Bungin. (2003). Analisis Data Penelitian Kualitatif. Jakarta: PT Raja Grafindo Persada.

Durkheim, Emile. (1995). The Elementary Forms of Religious Life. New York: The Free Press.

Hasan, Noorhaidi. (2009). "The making of public Islam: Piety, agency, and commodification on the landscape of the Indonesian public sphere." Contemporary Islam 3(3):229-50.

Mayasari, Ros. (2014). "Religiusitas Islam dan Kebahagiaan (Sebuah Telaah dengan Perspektif Psikologi)." Al-Munzir 7(2):5.

Menteri Agama Republik Indonesia. 2014. "Syarat dan Tata Cara Penghitungan Zakat Mal dan Zakat Fitrah Serta Pendayagunaan Zakat Untuk Usaha Produktif (Pasal 4)." simbi.kemenag.go.id 4. Diambil 14 Maret 2019 (http://simbi.kemenag.go.id/simzat/dow nload/files/syarat_dan_tata_cara_penghi tungan_zakat.pdf).

Moch. Fakhruroji. (2012). "Privatisasi Agama : Globalisasi dan Komodifikasi Agama." Jurnal Komunikata 193-211.

Moelong. (2012). Metode Penelitian Kualitatif. Bandung: Remaja Rosdakarya.

Mursalim. (2011). "Doa Dalam Perspektif AlQur'an Mursalim Sekolah Tinggi Agama Islam Negeri Samarinda." Jurnal Al-ULum 11:63-78.

Notoatmodjo, Soekidjo. (2003). Pendidikan Dan Perilaku Kesehatan. Jakarta: Rineka Jakarta Cipta.

Poloma, Margaret M. (2004). Contemporary Sociological Theory, Terjemah tim Yasogama. Jakarta: Rajawali Press.

Prof. Dr. Endang Widi Winarni, M. P. 2018. Teori dan Praktik Penelitian Kuantitatif Kualitatif. diedit oleh Retno Ayu Kusumanintyas. PT. Cahaya Prima Sentosa. 
Jurnal Sosiologi Pendidikan Humanis Vol 4, No 1, Juli 2019

Wardani. (2016). "Membedah Teori Sosiologi : Teori Pertukaran ( Exchange Theory) George Caspar Homans." Studia Insania Vol. 4 NO.(April):21.

Zainal, Asliah. (2014). "Sakral dan Profan dalam Ritual." Jurusan Dakwah STAIN Sultan Qaimuddin Kendari 9(1):61-71. 